\title{
Przed czym poetykę ratuje doświadczenie? Wstępne rozważania
}

\author{
Joanna Krajewska
}

\section{„(...) doświadczenie jest owocem pracy, przeżycie jest fantasmagorią przeżycia”.}

Walter Benjamin ${ }^{1}$

Kantowską antropologię filozoficzną fundują cztery pytania: co mogę wiedzieć?, co powinienem czynić?, czego mogę się spodziewać? i kim jest człowiek? Pierwsze - epistemologiczne - pyta o podmiot, warunki i granice poznania, drugie - etyczne - zaprasza do refleksji dotyczącej zadań i powinności człowieka, trzecie - teleologiczne - każe myśleć o celu i kresie życia, ale pozwala też podjąć namysł nad tym, co wykracza poza skończoność i przygodność bytu, zastanawiać się nad tym, na co możemy mieć nadzieję. Ostatnie - ontologiczne - stawia kwestię istoty i rozumienia bytu, jakim jest człowiek oraz wszelkie sprawy pochodne - kształtowanie się podmiotowości, sposobów jej istnienia w świecie. Nie czas i miejsce tu na przywoływanie odpowiedzi, które na tak postawione pytania udzielił filozof z Królewca. Powrót do nich na łamach pierwszego numeru czasopisma, którego tematem przewodnim jest „poetyka po poetyce”, mógłby wywołać niepokój uczestników i świadków kolejnych zwrotów w humanistyce, które ostatecznie osądziły i wydały wyrok na dorobek niemieckiego idealizmu, mającego w Kancie swego ojca założyciela. Przywołuję je, ponieważ - jako pytania - nie straciły nic ze swej mocy, nadal pozostają aktualne i w różnych okolicznościach spędzają sen z powiek humanistom, zasadne wydaje się także przeniesienie ich na grunt poetologii. Nade wszystko zaś chciałabym uczynić z nich heurystykę mojego wywodu, wskazując, iż każda teoria - słaba czy mocna, chcąc nie chcąc, musi się z nimi przynajmniej zetknąć. Heurystykę rozumiem tu po prostu jako oś kompozycyjną, ramę modalną wywodu. Skorzystać też jednak trzeba z jej najpowszechniejszej definicji jako wiedzy, której cel stanowi poszukiwanie i badanie optymalnych metod oraz reguł odnajdywania odpowiedzi na stawiane zapytania lub problemy. W moim tekście chciałabym się przyjrzeć wstępnie metodom i regułom stawiania problemów i odnajdywania odpowiedzi w wybranych tekstach polskich literaturoznawców, którzy podejmują post-poetologiczną refleksję i odpowiedzieć na zawarte w tytule artykułu pytanie.

${ }^{1}$ W. Benjamin, Pasaże, red. R. Tiedemann, przekł. I. Kania, posł. Z. Bauman, Kraków 2005, s. 843. 


\section{Poetyka po... czym?}

Refleksji literaturoznawczej zmierzyć się przyszło w ostatnich dekadach z filozoficznymi źródłami utraty bezpieczeństwa metafizycznego, oferowanego przez „wielkie narracje”. Źródła te scharakteryzował między innymi Richard Sheppard, który w pracy zatytułowanej Problematyka modernizmu europejskiego, będącej próbą syntezy europejskiego modernizmu (rozumianego jako prąd kulturowy obejmujący literaturę i sztukę schyłku XIX i pierwszego pięćdziesięciolecia XX wieku), zauważył, że u źródeł modernistycznej antropologii leży zmiana w postrzeganiu tego, co konstytuuje rzeczywistość i naturę ludzką oraz w odczuwaniu relacji między człowiekiem a rzeczywistością. Pierwsza z nich polegała na zakwestionowaniu newtonowskiego modelu wszechświata i euklidesowego pojmowania przestrzeni jako statycznej, niezmiennej i trójwymiarowej. Odkrycia Alberta Einsteina, Wernera Heisenberga czy Louis'a de Broglie udowodniły, że poza pozornie harmonijnym światem, który postrzegamy zmysłami, istnieje "metaświat” niemożliwy do opisania w kategoriach tradycyjnej fizyki przyczynowości, w którym obserwuje się nieciągłości, luki i brak regularności. Wzmiankowane odkrycia wzbudziły poczucie, że za dostępną potocznemu doświadczeniu rzeczywistością kryją się energie nieprzeniknione, a przez to niebezpieczne; przyczyniły się one również do redefinicji pojęć czasu i przestrzeni, kwestionowania zasadności ujmowania faktów w karby przyczynowo-skutkowych praw. Dziewiętnastowieczny humanista uważał, że człowiek obdarzony jest władzą rozumu, który pozwala sprawować kontrolę nad sobą samym, zło moralne i społeczne natomiast można według pozytywisty usunąć za pomocą wychowywania i reform. Jego optymizm etyczny i dobre samopoczucie zmącone zostały nowymi koncepcjami podmiotowości, wyrosłymi na gruncie tak zwanej Lebensphilosophie („filozofii życia”), którą uprawiali Artur Schopenhauer i Fryderyk Nietzsche (by wymienić tych najważniejszych) oraz freudowskiej psychoanalizy. Wspólną cechą tych szkół było przekonanie, że zachowanie człowieka determinowane jest pozaracjonalnymi siłami, tylko w ograniczonym stopniu poddaje się poznaniu i kontroli rozumu, wymuszającej stosowanie moralnych imperatywów:

(...) człowiek Zachodu - pisze Sheppard, podsumowując dokonania Freuda - poczuł się głęboko zaniepokojony, ponieważ zdał sobie sprawę, że stłumione bóstwa i moce psychiczne przez nie reprezentowane nie znikną tylko dlatego, że on tego chce. I choć może próbować ukryć przed sobą samym wynikające stąd cierpienie psychiczne przez takie sublimacje, jak religia, kultura i poszukiwanie wiedzy, takie przeniesienia w ostatecznym rozrachunku są pozbawione mocy ${ }^{2}$.

Psychoanaliza i „filozofia życia” inspirowały literaturę, która odtąd zaczyna się interesować destabilizacją osobowości bohaterów, wystawionych na działanie irracjonalnych sił, jakim wydawało się, że osiągnęli bezpieczną i stabilną tożsamość oraz demaskuje sposoby, dzięki którym iluzję tę udawało im się podtrzymywać. Jeśli chodzi o ostatnią zmianę, zmianę w postrzeganiu relacji człowieka i rzeczywistości, centralne dla doświadczenia modernistycznego jest poczucie wydziedziczenia, wygnania, radykalnego wyobcowania oraz nadchodzącej cywilizacyjnej katastrofy. Tragizm diagnozowanej sytuacji wzmacnia poczucie wydziedziczenia z języka. Ten ostatni okazuje się narzędziem niedoskonałym, arbitralnym i pozbawio-

\footnotetext{
${ }^{2}$ R. Sheppard, Problematyka modernizmu europejskiego, pzekł. P. Wawrzyszko, [w:] Odkrywanie modernizmu. Przekłady i komentarze, red. i wstęp R. Nycz, Kraków 2004, s. 104-105.
} 
nym lub pozbawiającym wiarygodności, zamykającym wszelkie dążenia człowieka (poznawcze roszczenia, możliwość ekspresji, samopoznania) w granicach jego językowego świata. Sheppard podaje wyczerpującą charakterystykę zachodzących zmian w zarysowanych przez siebie obszarach (modernizm jako diagnoza) oraz klasyfikuje strategie artystów, które pozwalały z nimi sobie jakoś poradzić, szukając ciągłości w nieciągłym świecie, lub takie, które nie znajdowały żadnych pozytywnych odpowiedzi i kontemplowały zgliszcza metafizycznego gmachu (modernizm jako odpowiedź). Innymi słowy, powiedzieć można, że wzmiankowane idee filozoficzne czy filozoficzne konsekwencje odkryć naukowych kazały przyjrzeć się krytycznie możliwościom pozytywnej odpowiedzi na przywołane przeze mnie pytania Kanta, podały też w wątpliwość prawomocność tez humanistyki, w tym literaturoznawstwa, i kazały przeformułować podstawowe założenia i modele pojęciowe obowiązujące na jego terenie.

Za próbę pozytywnej odpowiedzi literaturoznawstwa na modernistyczną problématique uznać można poetykę strukturalistyczną, której zasadność została jednak zakwestionowana przez refleksję poststrukturalistyczną. Rzec można, w dość dużym, ale efektownym, uproszczeniu, że argumentem oskarżenia stał się fakt, iż poetyka ta nie wyciągnęła ostatecznych wniosków z rozpoznanego kryzysu. Czy wzorem Sheppardowskiej klasyfikacji rzec by można jeszcze, że była ona odpowiedzią pozytywną na rozpoznaną problematyczność, natomiast poststrukturalizm, przynajmniej w swojej pierwszej fazie, negatywną?

Krytykę poetyki w jej wersji formalistyczno-strukturalistycznej, dokonaną w ramach tego ostatniego, omówiła wyczerpująco Anna Burzyńska w tekście Poetyka po strukturalizmie, umieszczonym najpierw w tomie studiów Poetyka bez granic (później dopiero w Anty-teorii literatury), bodaj pierwszej systematycznej publikacji próbującej zdać sprawę i odnieść się do konsekwencji kolejnych zwrotów w humanistyce. Badaczka wskazała, że refleksja poststrukturalistyczna piętnowała przede wszystkim nadmierną formalizację, fundamentalizm, aprioryzm, binaryzm (w tym kultywowanie opozycji wnętrza i zewnętrza), a nawet fetyszyzm czy sprzeniewierzenie się zdobyczom przełomu antypozytywistycznego poetyki oraz doprowadziła do wyraźnych dyslokacji w obszarze dyscypliny; najważniejsze z nich określiła natomiast jako przejście od systemu do (inter)tekstu, od gramatyki do retoryki, od nauki do literatury i od estetyki do ideologii ${ }^{3}$. W ślad za opisanymi przemieszczeniami szły zmiany strategii badawczej. Warto w tym miejscu zauważyć, że opisywane przez badaczkę ruchy układają się w porządek chronologiczny, w zagranicznej refleksji literaturoznawczej rozłożyły się jednak na kilka dekad, na grunt polskiej teorii literatury przeszczepione zostały natomiast w niewielkich odstępach czasowych. I tak przejście od systemu do (inter)tekstu prowadziło do porzucenia mrzonek o możliwości skonstruowania systemu na rzecz praktykowania interpretacji. Analiza strukturalna, skupiona na budowaniu skończonego modelu, ustąpić miała miejsca otwartej i nie mającej kresu analizie tekstualnej ${ }^{4}$, która umieszcza

\footnotetext{
${ }^{3}$ A. Burzyńska, Poetyka po strukturalizmie, [w:] Poetyka bez granic, red. W. Bolecki, W. Tomasik, Warszawa 1995, s. 57. Pięć lat wcześniej „Teksty Drugie” opublikowały głosy dwóch literaturoznawców, które warto w tym miejscu odnotować: Edwarda Balcerzana Zmianę stanu oraz Czy schodzimy na pobocze? Michała Głowińskiego. Co ciekawe, badacze ci formułowali stanowiska przeciwne - Balcerzan z niepokojem obserwował odwrót od poetyki, Głowiński natomiast postrzegał ją jako nadal istotną dziedzinę w „koncercie nauk”.

${ }^{4}$ Zob. A. Burzyńska, Poetyka po strukturalizmie, dz. cyt., s. 61.
} 
tekst w uniwersum innych tekstów, „rezygnując dobrowolnie z naukowych roszczen”” ${ }^{\text {. Dru- }}$ gie przesunięcie (od gramatyki do retoryki), które zawdzięczamy przede wszystkim lekcji dekonstrukcjonizmu, uwypukla znaczenie „tropologicznej” właściwości tekstów, a dalej niezbywalnej retoryczności wszelkiego typu dyskursów. Każe więc badaczom porzucić ich rozpatrywanie w kategoriach prawidłowości i podobieństw, a skupić się na przemieszczeniach, odchyleniach i nieciągłościach. Warto podkreślić w tym miejscu za badaczką, że dekonstrukcjonizm zwrócił również uwagę na problem statusu dyskursu teoretycznego, przypisując jemu tę samą co innym tekstom figuralność, a ponadto coś więcej - „złą wiarę”. Literatura „wie” o swojej figuralności, teorii natomiast wydaje się, że jest w stanie wypracować przejrzysty język opisu. Procesem równoległym do formułowania tych zarzutów jest rozwój literatury postmodernistycznej, która dostarcza post-poetyce (czy powiedzieć należałoby raczej post-poetykom) argumentów przeciwko poetyce strukturalnej (pisanej w tekście Burzyńskiej wielką literą) i wyznacza tym samym ramy kolejnego przejścia - od teorii do literatury:

U źródeł tego procesu tkwi zjawisko nasilającego się oporu najnowszej literatury wobec tradycyjnej poetyki. Zakwestionowanie restrykcyjnych wariantów Poetyki zbiega się tu z tendencją do zacierania granic pomiędzy dyskursem literackim i dyskursem teoretycznym, Ważną rolę odgrywają również w tym procesie przemiany samego dyskursu literackiego, który, stając się jednocześnie dyskursem o własnych regułach konstrukcyjnych, zaczyna przyjmować funkcję tradycyjnie przynależną poetyce. (...) Z jednej strony - podkreśla autorka [Christine Brooke-Rose - J.K.] - powieść sama staje się aktem poznania, który wyraźnie dominuje nad walorami czysto estetycznymi, z drugiej zaś - wypowiedzi czołowych teoretyków i filozofów upodabniają się maksymalnie do literatury ${ }^{6}$.

Jest to kolejny argument za osłabieniem rzeczywistej lub nieco rozbuchanej przez jej krytyków mocy Poetyki i uczynienie z niej poetyki pisanej małą literą - tu Burzyńska powołuje się na formułę Lindy Hutcheon - „otwartej, zmiennej struktury teoretycznej”, „elastycznej struktury konceptualnej”, "problematyki”. Tę ostatnią formułę warto zapamiętać, ponieważ znajdzie ona swoje miejsce w podtytule drugiego tomu Kulturowej teorii literatury, który brzmi Poetyki, problematyki, interpretacje. Nieco odmienny sposób postrzegania statusu poetyki po Poetyce, będącą jednak konsekwencją przemyślenia tych samych tez, proponuje konstruktywizm, znoszący rozdział między porządkami teorii i przedmiotów. W konstruktywistycznym ujęciu (reprezentowanym w tekście Burzyńskiej przez Briana McHale’a) poetyka staje się opowieścią. Ostatnie omówione przez badaczkę przesunięcie - od estetyki do ideologii (czy też od poetyki do polityki) - jest kolejną propozycją ujęcia przedmiotu dociekań literaturoznawczych. O ile poprzednie dokonywały się w łonie dekonstrukcjonizmu czy konstruktywizmu, o tyle to ostatnie otwiera drogę szeroko pojętym studiom kulturowym i kulturowej teorii literatury. Charakterystykę przemieszczenia rozpoczyna Burzyńska od przywołania słów Josepha Hillisa Millera, który w 1987 roku notował następującą prawidłowość:

\footnotetext{
5 Tamże, s. 62.

${ }^{6}$ Tamże, s. 67.

${ }^{7}$ Zob. L. Hutcheon, A Poetics of Postmodernism. History, Theory, Fiction, Nowy Jork-Londyn 1988.
} 
(...) prawie powszechny odwrót od teorii zwróconej w stronę języka jako takiego i równie silny zwrot w stronę historii, kultury, społeczeństwa, polityki, instytucji, uwarunkowań klasowych i płciowych, kontekstu społecznego i bazy materialnej8.

Było to zaproszenie dla nielubianego przez strukturalizm, szeroko pojętego kontekstu, które zaowocowało nową poetyką - „poetyką kultury”. Autorem tego terminu jest Steven Greenblatt, stawiający przed nią misję badania sposobów kształtowania się praktyk kulturowych i analizowania relacji między nimi, opisania procesów formowania zbiorowych doświadczeń oraz modalności ich przejawiania się w dominujących formach estetycznych. Metoda ta łączy, wskazuje Burzyńska, „wątki Foucaultowskiej analizy dyskursu, neo-marksistowskiej krytyki ideologicznej, neo-pragmatyzmu, Derridowskiej koncepcji tekstualności i krytyki retorycznej” oraz w pełni akceptuje i eksponuje także własne „uwikłania w sieć relacji łączących dyskursy literackie i inne porządki - społeczne, historyczne, polityczne i ekonomiczne" ${ }^{\prime}$. Ujęcie to znosi sztywną na terenie Poetyki granicę między tym, co literackie i nieliterackie, traktując literaturę jako jeden $\mathrm{z}$ rodzajów dyskursu, który za pomocą wypracowanych metod można badać albo za pomocą której badać można sformułowane problematy. Pokrewne intencje dostrzega badaczka w ujęciach poetyk powstałych na gruncie amerykańskiego feminizmu, wzmiankując redagowany przez Nancy K. Miller zbiór The Poetics of Gender oraz pracę Elaine Showalter Towards a Feminist Poetics ${ }^{10}$.

Dodać trzeba, że omówione przez Burzyńską, a przywołane przeze mnie w tym miejscu przemiany dokonują się na jednej z dwóch gałęzi genealogicznego drzewa poetyki po strukturalizmie. Charakterystyka tej drugiej również stanowi przedmiot zainteresowania badaczki. W dużym skrócie powiedzieć można, że równolegle dokonuje się rozwój takiej odmiany poetyki, która akceptuje lingwistyczny model strukturalizmu i swoje wysiłki koncentruje wokół przezwyciężenia trudności jego ortodoksyjnej wersji oraz poszerzenia jej o zdobycze socjolingwistyki, teorii aktów mowy czy teorii komunikacji.

Tekst Burzyńskiej pełni funkcję informacyjną, choć widać wyraźnie, że sympatie autorki lokują się po stronie poetyk w liczbie mnogiej i najbardziej interesuje ją docelowe miejsce opisywanych przez siebie przemieszczeń. Można powiedzieć, że traktuje o problematyczności Poetyki i ukazuje różne sposoby przepracowania tej problematyczności (poetyka jako diagnoza i poetyka jako odpowiedź), nie przekłada ich jednak na grunt polskiego literaturoznawstwa ani nie projektuje nowego typu badań. Zdaje sprawę z epistemologicznych trudności, nie mówi, co czynić i na co mieć nadzieję.

Tom Poetyka bez granic, z którego pochodzi artykuł Burzyńskiej, ma według mnie symptomatyczny tytuł. Po kolejnych zwrotach i zmąceniach dyscyplinarnej czystości, zmianach paradygmatu i przeformułowaniach wydawać się mogło, że dziedzina ta utraciła swe sztywne i nieprzepuszczalne dotąd granice. Jak wiadomo, terytoria bez granic padają łatwym łupem

\footnotetext{
${ }^{8}$ J. Hillis Miller, Presidental Adress. The Triumph of Theory, the Resistance to Reading, and the Question of Material Base, [w:] tegoż, Theory Now and Then, Durham 1991, cyt. za: A. Burzyńska, Poetyka po strukturalizmie, dz. cyt., s. 70.

${ }^{9}$ A. Burzyńska, Poetyka po strukturalizmie, s. 71.

${ }^{10}$ The Poetics of Gender, red. N.K. Miller, Nowy Jork 1986; E. Showalter, Towards a Feminist Poetics, [w:] Women, Writing, and Writing about Women, red. M. Jacobus, Londyn - Nowy Jork 1979.
} 
różnych kolonizatorów. Niebezpieczeństwa, które czyhają na pozbawioną twardej definicji literaturoznawczego przedmiotu poetykę, dostrzeże, scharakteryzuje i wyciągnie z nich konsekwencje dla swojej propozycji Ryszard Nycz - omówię ją w dalszej części mojego wywodu. Zanim jednak przejdę do dociekań krakowskiego badacza, chciałabym się przyjrzeć ustaleniom Doroty Korwin-Piotrowskiej z jej tekstu Życie pośmiertne poetyki, zamieszczonego w numerze „Tematów i Kontekstów” poświęconym teraźniejszości i przyszłości tej dziedziny.

\section{Poetyki po poetyce}

Korwin-Piotrowska daje opis pozagrobowego życia dyscypliny. Czy jest to w wydaniu autorki nowego podręcznika do poetyki życie wskrzeszonego, czy widma? Opis ów rozpoczyna od ważnej uwagi, że termin „poetyka” jest obecnie poddawany niezliczonym zabiegom neosemantyzacji i pojawia się w różnych - zaskakujących często - zbitkach. Pozwala to zdefiniować ją bardzo ogólnie jako „sposób, w jaki coś jest zorganizowane czy zbudowane” ${ }^{11}$. W tej formule okazuje się ona dziedziną wszechogarniającą swymi strategiami wszelkiego typu dyskursy, a także te przedmioty, które ujawniają swój dyskursywny charakter. Następnie badaczka gromadzi i grupuje zarzuty formułowane wobec poetyki, które w istocie okazują się zarzutami nie wobec jej bezprzymiotnikowej wersji, a wobec poetyki strukturalistycznej. Powołując się na prawo psychologii społecznej mówiące o tym, że przekonania odmienne od tych, które dzielimy, jesteśmy skłonni traktować jako bardziej radykalne oraz tezę Nycza o retroaktywnym charakterze ludzkiego bycia w świecie ${ }^{12}$, Piotrowska stawia ciekawą hipotezę, że być może takiej poetyki - jak ją widzą i opisują jej poststrukturalistyczni krytycy - nigdy nie było (drenując dalej metaforę życia i śmierci poetyki, powiedzieć można, iż nigdy ona nie umarła). Po co to robią? badaczka nie formułuje takiego pytania wprost, ale daje na nie, przywołując gest zaniechania działania tytułowego bohatera książki Hermana Melville’a Kopista Bartleby, zakamuflowaną odpowiedź. Znienawidziwszy swoją kancelaryjną robotę oraz szefa, kopista przestał wykonywać swoje obowiązki, komunikując tę decyzję za pomocą formuły „wolałbym nie”. Zamiast odmowy działania wobec stwierdzonej anachroniczności i nieadekwatności propozycji poetyki strukturalistycznej Korwin-Piotrowska proponuje spojrzenie na status i miejsce tej dziedziny w nowym świetle:

Jeśli przekroczymy zarysowany różnymi zastrzeżeniami i kategorycznymi sądami Rubikon, dostrzeżemy odmienność, a zarazem komplementarność zjawisk, które nawet jeśli są przeciwstawne na poziomie nazw i pojęć (jak esencjalizm i pragmatyzm, model i kreacja, interpretacja i użycie) - współistnieją obok siebie jako różne sposoby konceptualizacji humanistycznego obszaru ustanawiania relacji między sposobem patrzenia, sposobem nazywania i opisu oraz tym, co jest przedmiotem oglądu. Poetyka już istnieje w szerszym, a zarazem bardziej metaforycznym sensie jako obszar badań związanych z ekspresją ludzkiego doświadczenia i umiejętnościami poznawczymi, oraz w węższym i bardziej związanym z tekstem znaczeniu jako dziedzina zajmująca się badaniem właściwości utworów ${ }^{13}$.

\footnotetext{
${ }^{11}$ D. Korwin-Piotrowska, Życie pośmiertne poetyki, „Tematy i Konteksty” 2013, nr 3, s. 20-21.

${ }^{12} \mathrm{Nycz}$ notuje, iż to, co robi człowiek, „ku czemu zmierza, zmienia w pewnej mierze i to, kim dotąd był i świat, którego doświadcza”. R. Nycz, Od teorii nowoczesnej do poetyki doświadczenia, [w:] Kulturowa teoria literatury 2. Poetyki, problematyki, interpretacje, red. T. Walas, R. Nycz, Kraków 2012, s. 54.

${ }^{13}$ D. Korwin-Piotrowska, Życie pośmiertne poetyki, dz. cyt., s. 23-24.
} 
Ten koncyliacyjny charakter rozważań badaczki pozwala jej dalej sformułować optykę, w ramach której opozycyjne względem siebie perspektywy ująć można jako takie, które nie znoszą się nawzajem, co więcej, dają się połączyć. Korwin-Piotrowska wskazuje na dynamiczny charakter i historyczną zmienność tej dziedziny. Nie może ona i nie pozostaje oczywiście obojętna wobec zwrotów, które dokonały się w humanistyce, tyle że zmiany z nich wynikające każe rozpatrywać w stopniu proporcjonalnym do tego, w jakim reaguje na nie literatura. Poetyka dziś to dla niej „zbiór pytań i ponawianych wciąż prób odpowiedzi, opis i ekspresja, a nie zbiór założeń” ${ }^{14}$. W tym sensie jest ona „szkołą analitycznego myślenia przydatną w rozpoznawaniu semiotycznych przestrzeni człowieka"15. Korwin-Piotrowska zdaje sobie nic nie robić z roztrząsań na temat różnic przedmiotów humanistyki i nauk przyrodniczych oraz licznych wątpliwości dotyczących możliwości sformułowania definicji literatury. Bartleby wobec tych licznych „hermeneutyk podejrzeń” powiedziałby „wolałbym nie”, badaczka mówi zdroworozsądkowe „nie przesadzajmy”:

Nawiasem mówiąc, jakaś forma „literaturocentryzmu” w gronie literaturoznawców (podobnie jak wśród farmaceutów koncentracja na ważnych dla ludzkiego organizmu związkach chemicznych, a wśród astronomów na gwiazdach, planetach itp.) wydaje się czymś, co powinno być najbardziej naturalne, a nie odczuwane jako krępujące - przy jednoczesnej potrzebie ciągłej asymilacji zachodzących w kulturze i literaturze zmian oraz dialogu z całością humanistyki, a także samowiedzę związaną z malejącą wciąż społeczną rolą literatury ${ }^{16}$.

Warto dodać, że mówi to też jako nauczycielka akademicka - czego bowiem uczyć adeptów literaturoznawstwa, jeśli uwierzymy, że jego przedmiot zniknął pod naporem tez różnych filozofów i antropologów? Przedmiot poetyki staje się w tym sensie ideą regulatywną - nie wiemy, czy istnieje, ale żyć powinniśmy tak, jak gdyby istniał. Korwin-Piotrowska deklaruje też, iż wierzy w sensowność podejmowania debaty na temat roli i miejsca poetyki czy też poetyk w kulturze zaufania, choć to ostatnie miałoby być względne. Propozycja badaczki jest z ducha kognitywistyczna, gdy pisze, że o pojęciach wypracowywanych na gruncie tej dyscypliny myśleć trzeba jako o „zapisach poznawczego wysiłku, by zbadać i opisać pracę ludzkiego umysłu, wyobraźni oraz języka"17 czy wskazuje, iż wszelkiego rodzaju pojęcia albo kategoryzacje są jednocześnie konstruktami operacyjnymi, jak i rodzajami konceptualizacji danego zagadnienia. A z jej praktycznego, nastawionego na dydaktykę literatury na wszystkich poziomach kształcenia podejścia wynika zarysowany pod koniec tekstu projekt (zrealizowany w napisanym przez nią podręczniku), który wykorzystuje doświadczenie creative i uncreative writing oraz o oznacza podtrzymanie związków poetyki z lingwistyką, także wejście w obszar uważnego czytania oraz inwencji, twórczości.

Poetyka wcale więc nie umarła, licznym rozproszeniom uległ jej przedmiot, co nie pozwala nam jednoznacznie i pewnie odpowiedzieć na sformułowane na samym początku wywodu pytanie o to, co możemy wiedzieć. Brak tej odpowiedzi w świetle tekstu Korwin-Piotrowskiej nie przesądza jednak o tym, że nie wiadomo, na co można mieć nadzieję i co czynić.

\footnotetext{
${ }^{14}$ Tamże, s. 25.

${ }^{15}$ Tamże.

${ }^{16}$ Tamże.

${ }^{17}$ Tamże, s. 29.
} 


\section{Przed czym poetykę ratuje doświadczenie?}

"Chyba o żaden termin nie spierano się ostatnio w kulturowych debatach anglo-amerykańskich - zaczyna swój wywód Martin Jay - tak gorąco jak o "doświadczenie»" ${ }^{18}$. Spierano się o nie i napisano na jego temat tak wiele, że nie sposób choćby przywołać w tym miejscu kluczowych koncepcji. Interesują mnie szczególnie takie konceptualizacje tej kategorii, które pozwoliły niektórym ich autorom przezwyciężyć, będący wynikiem poststrukturalizmu, impas humanistyki. Sprawę komplikuje fakt, że dla poststrukturalizmu doświadczenie było kategorią podejrzaną, najczęściej identyfikowaną z naiwnym empiryzmem czy fenomenologią. Należało więc znaleźć inną - bardziej przekonującą i filozoficznie doniosłą - formę refleksji o doświadczeniu. Świetnie streszcza tę trudność w dalszej części swojego wywodu Jay:

(...) owi krytycy rzekomo fundamentalistycznego pojęcia doświadczenia, a nie są to odosobnione przypadki, biorą sporą część amunicji z rzekomych lekcji udzielonych przez myśl poststrukturalistyczną, która, jak twierdzą, zadaje śmiertelny cios pojęciu spójnej podmiotowości, zakreślając granice jakiejkolwiek wiary w oczywistość doświadczenia. Dla takich krytyków (...) dyskurs, tekstualność, język i struktury władzy dostarczają matrycę, z której wyłania się doświadczenie, a nie odwrotnie. A zatem założenie doświadczenia jako podstawy jest wprowadzającym w błąd przypisywaniem zdolności konstrukcyjnej czemuś, co samo jest jedynie retorycznie czy dyskursywnie skonstruowaną kategorią. (...) Potępiają oni samo poszukiwanie autentycznego doświadczenia zagubionego w nowoczesnym świecie jako kolejną wersję nostalgicznej tęsknoty za obecnością i bezpośredniością, która nigdy nie istniała i istnieć nie moż $\mathrm{e}^{19}$.

We wszystkich omawianych przypadkach - wskazuje autor Songs of Experience i historyk szkoły frankfurckiej - atak przypuszcza się na jedną z dwu konceptualizacji: Erlebnis lub Efahrung, tymczasem z twórczości Georges’a Bataille’a i Michela Foucaulta, poststrukturalistów przecież, wyczytać można drogę, która pozwala przekroczyć horyzont wyznaczony przez tradycję filozoficzną obydwu konceptów oraz binarnej opozycji doświadczeniowa bezpośredniość-dyskursywna mediacja doświadczenia ${ }^{20}$. Śledząc progi i granice doświadczenia w nowoczesności, Anna Zeidler-Janiszewska ${ }^{21}$ przypomina, że i inni spadkobiercy humanistycznych zwrotów - w różnych formach i znaczeniach - upomnieli się o tę kategorię. Na przykład Frank Ankersmit wprost uznał ją za antidotum na skutki kryzysu reprezentacji, które ujawniły się ze szczególną mocą w refleksji teorii historii nad problematyką Zagłady. Z kolei autorzy tekstów pomieszczonych w tomie The Anthropology of Experience pod redakcją Victora Turnera i Edwarda Brunera mówią o roli doświadczenia jako źródłowej metafory mającej moc reorganizacji pola humanistycznych dociekań. Przywoływane przez siebie przykłady Zeidler-Janiszewska podsumowuje stwierdzeniem, że całą nowożytną filozofię widzieć można jako swoistą teorię (czy metateorię) doświadczenia.

\footnotetext{
${ }^{18}$ M. Jay, Granice doświadczenia granicznego: Bataille i Foucault, przekł. M. Kwiek, [w:] „Nie pytajcie mnie, kim jestem..." Michel Foucault dzisiaj, red. M. Kwiek, Poznań 1998, s. 37.

${ }^{19} \mathrm{M}$. Jay, Granice doświadczenia granicznego..., dz. cyt., s. 39.

${ }^{20}$ Zob. tamże, s. 59. „Jest (...) wielką zasługą Foucaulta, Bataille’a i innych tak zwanych poststrukturalistycznych obrońców jego [doświadczenia - J.K.] znaczenia - pisze Jay - że zmusili nas do wykroczenia poza jałowy wybór pomiędzy naiwną doświadczeniową bezpośredniością a nie mniej naiwną dyskursywną mediacją tego doświadczenia, który o wiele za długo wydawał się naszą jedyną alternatywą".

${ }^{21}$ A. Zeidler-Janiszewska, Progi i granice doświadczenia (w) nowoczesności, [w:] Nowoczesność jako doświadczenie, red. R. Nycz, A. Zeidler-Janiszewska, Kraków 2006. Dalsze informacje w tym paragrafie podaję za badaczką.
} 
Nyczowi za drogę wykraczającą poza wzmiankowany wyżej horyzont opozycji posłuży literatura. Teksty, które projektują jego poetykę doświadczenia, złożyły się na wydaną w 2012 roku książkę pod tym samym tytułem, wcześniej natomiast publikowane były w różnych miejscach; te, które dają fundamenty teorii, badacz wydrukował najpierw w dwu tomach Kulturowej teorii literatury. Autor Sylw wspótczesnych dokładnie - rzec by można nieco poetycko, intensywnie - przemyślał konsekwencje kolejnych wspominanych już tu wielokrotnie zwrotów i skłonny jest widzieć je jako zagrażające literaturoznawstwu. Korwin-Piotrowska przeszła nad nimi do porządku dziennego, Nycz zagląda im prosto w oczy. Retoryka zagrożenia zastosowana w tekście inicjującym jego projekt Kulturowa natura, słaby profesjonalizm. Kilka uwag o przedmiocie poznania literackiego i statusie dyskursu literaturoznawczego prowokuje, by wykładnię poetyki doświadczenia czytać jako jego obronę. Spójrzmy na te niebezpieczeństwa i sposób ich ujęcia:

Czyż wrzawa metodologicznych sporów (faktycznie cichnąca stopniowo, a coraz częściej jedynie rutynowo ożywiana) nie przesłania jedynie niewypowiadalnego dramatyzmu sytuacji teoretycznego dyskursu, skazanego na manifestowanie samozadowolenia z powodu nie ograniczonego niczym zasięgu jego poszukiwań - przy braku jakichkolwiek zgodnie uznawanych atrybutów jego odrębności i tożsamości? Odgrodzić się zatem (i zgodzić na marginalizację) czy raczej dążyć do zyskania na społecznym znaczeniu (za cenę roztopienia się w badaniach kulturowych)? (...) A może lepiej schronić się we własnej naukowej (sub-subdyscyplinowej) niszy i próbować przeczekać teoretyczne zawieruchy, w nadziei, że solidny warsztat filologa zawsze się obroni? (...) Wśród wielu spornych problemów teoretycznych ten dotyczący racji bytu naszej profesji - miejsca literatury i statusu literaturoznawstwa - jest dziś z pewnością problemem bezspornym [wyróżnienia moje - J.K.] $]^{22}$.

W tej groźnej sytuacji pierwszą potrzebą wydaje się przywrócenie poznawczego wymiaru literaturze oraz jej badaniu, a także adkrycie fundamentów swoistości literaturoznawczego dyskursu. Znajdzie je Nycz w Iserowskim rozróżnieniu fikcji eksplanacyjnych (nauki przyrodnicze) i eksploracyjnych (humanistyka) ${ }^{23}$, a nade wszystko w koncepcji tekstu jako sposobu poznania Theodora Adorna. Ta ostatnia, wyłożona w studium Lekcja Adorna: tekst jako sposób poznania albo o kulturze jako palimpseście, daje możliwość wyjścia poza dwa zagrażające literaturoznawstwu opozycyjne stanowiska epistemologiczne - realizm i konstruktywizm. Kluczowe znaczenie w przedefiniowanym procesie poznania będzie miało natomiast doświadczenie:

(...) pozwala [ono - J.K.] przełamać ów przymus utożsamiania, przeniknąć bądź rozmontować fasadowy obraz zamkniętego, jednolitego, niezmiennego bytu - i wejść w kontakt z tym, co nietożsame, inne, niepowtarzalne, co osadza się czy zostawia ślad w jego nieuświadamianych warstwach $^{24}$.

\footnotetext{
${ }^{22} \mathrm{R}$. Nycz, Kulturowa natura, słaby profesjonalizm. Kilka uwag o przedmiocie poznania literackiego i statusie dyskursu literaturoznawczego, [w:] Kulturowa teoria literatury. Główne pojęcia i problemy, red. M.P. Markowski, R. Nycz, Kraków 2006, s. 33-34.

${ }^{23}$ Zob. W. Iser, Czym jest antropologia literatury? Różnica między fikcjami wyjaśniającymi a odkrywającymi, przekł. A. Kowalcze-Pawlik, „Teksty Drugie” 2006, nr 5, s. 11-35.

${ }^{24} \mathrm{R}$. Nycz, Lekcja Adorna: tekst jako sposób poznania albo o kulturze jako palimpseście, [w:] tegoż, Poetyka doświadczenia, Warszawa 2012, s. 76.
} 
Szczególną rolę odgrywa w opisywanym przez Nycza procesie doświadczania świata i siebie literatura. Nie daje się ona opisać w kategoriach ekspresji czy reprezentacji, nie tyle jest informatorką o świecie czy sposobie jego poznawania, ile ma moc sięgania głębiej, jako jedyny typ dyskursu daje dostęp do tego, co „bez jej wynalazczej interwencji nie doszłoby do swego uobecnienia"25.

Autor Tekstowego świata proponuje („słabą”) teorię, która odpowiada na wszystkie przywołane przeze mnie kantowskie pytania. Wyznacza granice i cel (literaturoznawczego) poznania. Przynosi definicję literatury i przedmiotu literaturoznawstwa, opisując metody działania (interpretacja, studium przypadku) - wskazuje, co czynić, nade wszystko pozwala jednak myśleć o tym, co wykracza poza horyzont tego, co dane.

Wstępnym rozpoznaniem, które chciałabym w tym miejscu uczynić, jest obserwacja, że literaturoznawca czy literaturoznawczyni, złapani w pułapkę poststrukturalistycznego impasu i opozycji realizm-konstruktywizm, chwytać się będą różnych strategii ratunku. W tym sensie poetyka po poetyce jawić się może jako historia (historia do napisania) reakcji na swe położenie. Wydaje się, że uwięzieni mają kilka możliwych strategii działania: mogą podjąć próbę wydostania się z potrzasku, pozostać w niej i zaprzeczyć temu faktowi, uparcie twierdzić, że pułapka nie istnieje lub pozostać w niej w geście rezygnacji, sądząc, że nic poza nią nie istnieje.

SŁOWA KLUCZOWe $\mid$ Abstrakt $\mid$ Nota o aUtorze 


\section{SEOWA KLUCZOWE:}
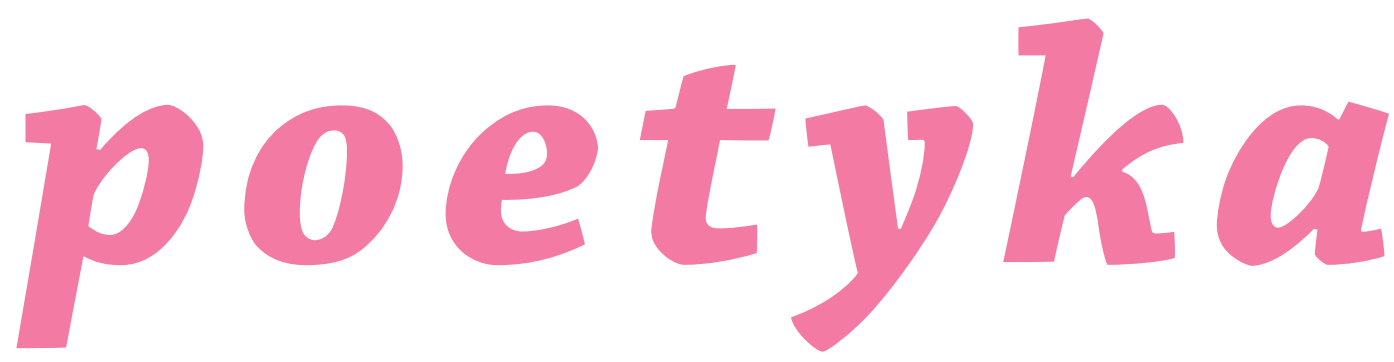

A B S T R A K T :

Autorka analizuje metody i reguły stawiania problemów i odnajdywania odpowiedzi w wybranych tekstach polskich literaturoznawców, którzy podejmują refleksję nad miejscem poetyki we współczesnym dyskursie literaturoznawczym i pokazuje, że wyjściem z poststrukturalistycznego impasu stać się może kategoria doświadczenia. 


\section{doświadczenie}

\section{N O T A O A U T O R Z E :}

Joanna Krajewska - doktor nauk humanistycznych, autorka książki Spór o literaturę kobieca w Dwudziestoleciu międzywojennym (Poznań 2014). Jej zainteresowania naukowe skupione są wokół historii literatury pierwszej połowy XX wieku, teorii badań literackich, biografistyki oraz empirycznych badań nad odbiorem i psychologią czytania. Stale współpracuje z Zakładem Literatury XX wieku, Teorii Literatury i sztuki Przekładu w Instytucie Filologii Polskiej Uniwersytetu im. Adama Mickiewicza w Poznaniu.

s t r u k t uralizm 